\title{
Beloved Heritage - Condemned Heritage. About the handling of fortification heritage within the border region Germany-France-Luxembourg
}

Un patrimoine aimé ou condamné : le traitement du patrimoine militaire dans la région transfrontalière Saar-Lor-Lux

Geliebtes Erbe - verachtetes Erbe. Der Umgang mit dem festungsbaulichen Erbe in der Grenzregion Deutschland-Frankreich-Luxemburg

\section{Anja Reichert-Schick et Ingo Eberle}

\section{OpenEdition}

\section{Journals}

Édition électronique

URL : http://journals.openedition.org/rge/3302

DOI : $10.4000 /$ rge.3302

ISSN : 2108-6478

Éditeur

Association des géographes de l'Est

Édition imprimée

Date de publication : 30 mai 2011

ISSN : 0035-3213

\section{Référence électronique}

Anja Reichert-Schick et Ingo Eberle, «Beloved Heritage - Condemned Heritage. About the handling of fortification heritage within the border region Germany-France-Luxembourg », Revue Géographique de l'Est [En ligne], vol. 51 / 1-2 | 2011, mis en ligne le 18 janvier 2012, consulté le 08 septembre 2020. URL : http://journals.openedition.org/rge/3302 ; DOI : https://doi.org/10.4000/rge.3302

Ce document a été généré automatiquement le 8 septembre 2020.

Tous droits réservés 


\section{Beloved Heritage - Condemned Heritage. About the handling of fortification heritage within the border region Germany-France- Luxembourg}

Un patrimoine aimé ou condamné : le traitement du patrimoine militaire dans la région transfrontalière Saar-Lor-Lux

Geliebtes Erbe - verachtetes Erbe. Der Umgang mit dem festungsbaulichen Erbe in der Grenzregion Deutschland-Frankreich-Luxemburg

Anja Reichert-Schick et Ingo Eberle

\section{Introduction}

1 In many places fortifications ${ }^{1}$ constitute significant sites with high potential for leisure and tourism. Even the UNESCO World Heritage List documents, that fortifications and defensive structures are part of the entire world's cultural history. The World Heritage List includes more than fifty fortifications and defensive structures. In the year 2008, twelve French fortifications originating in the 17th century were added to the UNESCO World Heritage list. Hence, it seems to be self-evident to preserve and valorise fortifications as cultural heritage. Yet it does not apply to all countries equally.

2 This contribution focuses on the situation in the border region Germany-FranceLuxembourg. With centuries passing, a multiplicity of fortifications and complex defence systems arose in this region due to border shiftings between these states. Therefore, one can absolutely agree with the statement of the geographer Francois Reitel from Metz, who once said: The region Saar-Lor-Lux is "the biggest open-air museum of the world concerning fortifications" (Reitel 1993). Today, these 
fortifications representing cultural heritage pose a great challenge and this article focuses on the different handling of fortified places.

3 First of all, this article will give an introduction into the genesis and geographical distribution of the fortifications in the border region. The main part deals with the handling of fortifications in the different regions. Finally, the paper exemplifies measures increasing the acceptance of fortifications as cultural heritage.

\section{I - Fortifications in the border region Germany-France- Luxembourg: genesis and geographical distribution}

\section{A - Genesis of the fortifications}

4 The border region Germany-France-Luxembourg is composed of four different countries' regions. The biggest part belongs to France's region Lorraine. It is followed by the German part with the core area Saarland. Also the Grand Duchy of Luxembourg belongs to this region and last but not least parts of Belgium. However, the Belgian part is irrelevant since there are no fortifications of the Modern History in this area.

5 Since the Middle Ages the border region Germany-France-Luxembourg is a hard-fought area. The German western and respectively the French eastern border shaped up in an over 1000 years lasting process. Various conflicts caused the construction of numerous fortifications. Thus, cultural assets came into existence by the means of war.

6 In particular, the period from the 16th century on is relevant for the militarization of the region Saar-Lor-Lux. During that period, medieval weapons like catapults, pitch and brimstone were replaced by firearms operating with gunpowder. The invention of firearms initiated a revolution in fortification systems, which generated within five centuries three epochs of fortification construction (Reichert, 2005):

7 The time between the 16th and 18th century was dominated by the early modern period with its bastion-like fortress towns and citadels. In most cases they are characterised by symmetrically erected buildings that often form a star with its geometric elements. In the course of the conflicts between Emperor Charles V and the King of France Francis I, the first bastion-like fortifications in the border region were built. In the 17th century, these fortifications were continued by Louis XIV, who tried to enforce his predomination in Europe during four wars. 


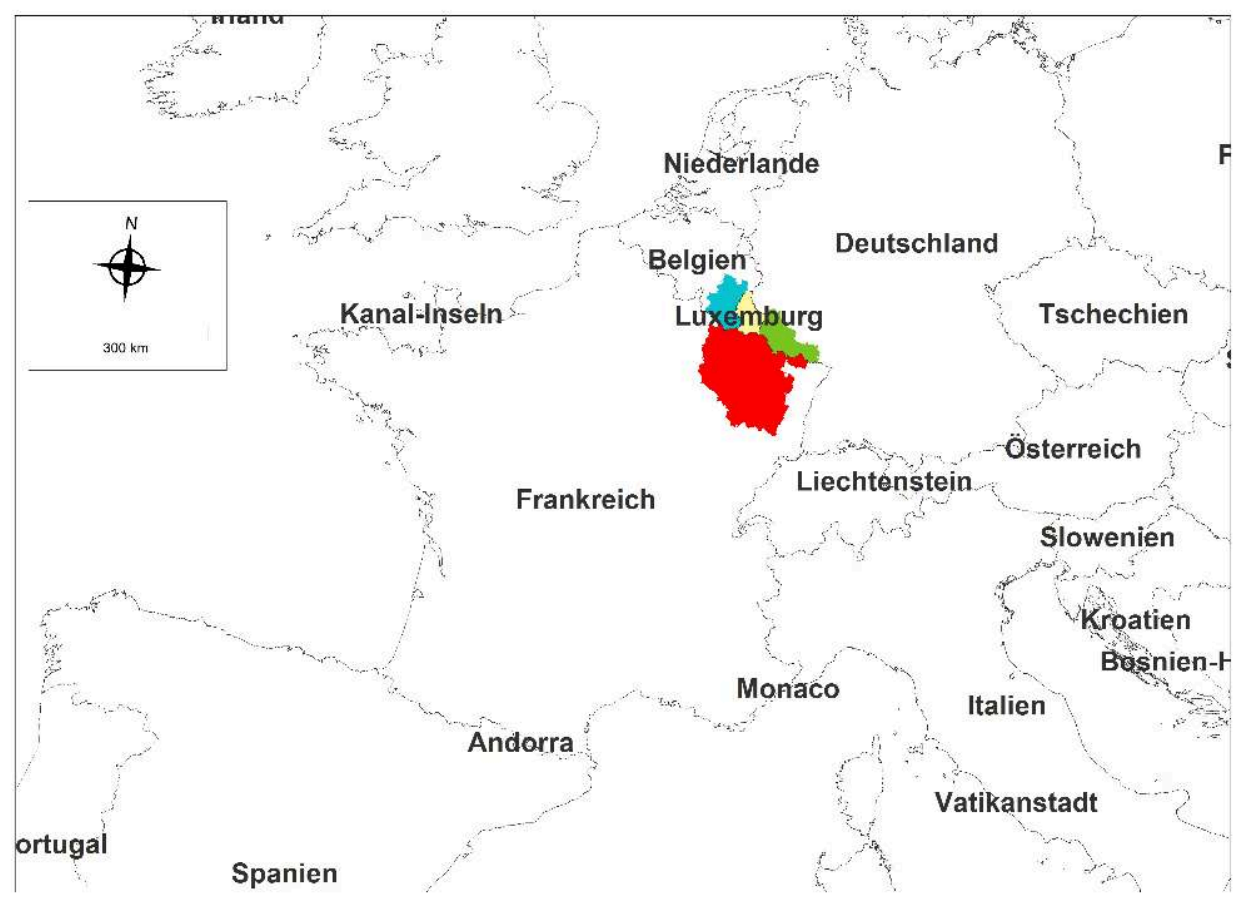

Figure 1 The border region Germany-France-Luxembourg and its position in Europe.

During the 19th century arose the epoch of forts and ring fortifications. In this time the safety of a place to defend was ensured by means of a ring consisting of up to 40 forts. In this way numerous towns became ring fortifications with a diameter of up to $70 \mathrm{~km}$. These ring fortifications were built towards the end of the 19th century and expanded until World War I. France as a defeated party in the Franco-Prussian War 1870/71 had to cede Alsace and parts of Lorraine to the German Reich. Thus both countries were facing a new border line with a length of more than $200 \mathrm{~km}$ (125 miles) which was to be fortified. Altogether about 140 major and a number of minor forts have been erected in that epoch.

9 The last epoch in the 20th century is characterised by the territorial fortifications built as straight-line defensive structures with dugouts and subterraneous sites made from concrete. During the time between the two world wars, these fortifications were built in many European countries (Eberle, 1995). Since in the contract of Versailles the borderline between Germany and France has been corrected on behalf of France, once again a refortification was required in both countries. In 1929, along this still existing frontier the French built the Maginot Line which consists of miles long subterraneous corridors. Starting in 1936 the Germans built the Siegfried Line with approximately 17000 separate bunkers.

10 So the region Saar-Lor-Lux has been massively militarized throughout five centuries and nowadays features an unusual large amount and variety in fortifications and defensive structures from the above mentioned three epochs. 


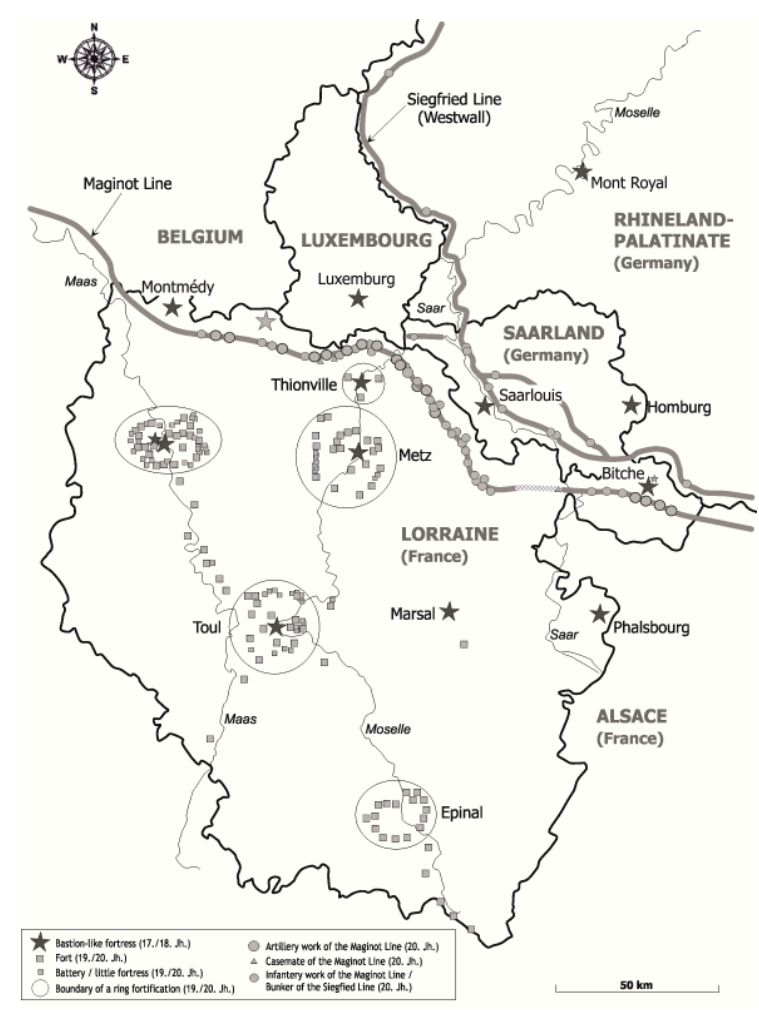

Figure 2 Fortifications in the border region Germany-France-Luxembourg.

\section{B - Number and geographical distribution}

In the region Saar-Lor-Lux exist not less than:

- thirteen bastion-like fortifications in all partial territories of the border region,

- 109 French forts and 34 forts and fortification structures from the second epoch of fortification architecture, which are solely located in French Lorraine,

- as well as the both straight-line territorial fortifications of the 20th century: the Maginot Line with its 53 main fortification sites in Lorraine and the Siegfried Line with still approximately 400 preserved bunker facilities in the German part of the border region. Due to the small size of the Siegfried Line's bunkers, their hidden location and their limited value for tourism, the importance of that high number is relatively low compared to the 53 structures of the Maginot Line.

Concerning the geographic distribution of fortifications within the border region two aspects are primarily striking: On the one hand the great treasure of fortifications is mainly allocated on one side namely the French side. $70 \%$ of the bastion-like fortifications, $100 \%$ of the forts and ring fortifications and in addition the Maginot Line are allocated in today's France (Lorraine). However, only a single fortification is located in Luxembourg, namely that in the capital. Finally, on the German side of the border region there is only the Siegfried Line with its round about 400 intact bunkers in addition to the three bastion-like fortifications. But it is their valorization that is still very problematic as shown later on. On the other hand, due to the border shiftings fortifications of the respective countries are partly allocated outside their present territory. Thus, all ring fortifications erected by the Germans after 1871 are allocated in today's French part of the border region. This circumstance affects also the fortifications of Saarlouis and Mont Royal. These are former French fortifications which 
today belong to the German territory. This construction activity illustrates all the more the common and closely interconnected history of this border region. Hence, today German as well as French fortification heritage is allocated in the respective bordering country causing on the one hand problems of acceptance, on the other hand implicating a border-crossing valorization and a stronger awareness of the respective neighbor.

After this historic-geographic overview we want to attend to the core: How do the countries deal with the fortification sites and what options do exist to organize sustainable cross-border utilization?

\section{II - Handling of fortifications in the different areas of the border region}

\section{A - France - Self-confident handling, however overwhelmed by the great number of structures}

First of all, the article glances at France. There fortifications are acknowledged as cultural assets without doubt, and the sites opened to the public are presented with certain patriotism. In addition, a lot is invested in the valorisation of this heritage, whereby considerable fortification tourism has developed.

But the French part of the border region has to bear the burden of being endowed with plentifulness of fortifications. Because of the multitude, it seems impossible to valorise all buildings and prevent them from deterioration. Considering, for example, only the fortifications and affiliated structures like barracks erected between 1871 and 1914, there are almost 1000 buildings from that epoch ${ }^{2}$. Due to that fact, Lorraine pursues the strategy to maintain only a few fortifications and to make them accessible to public.

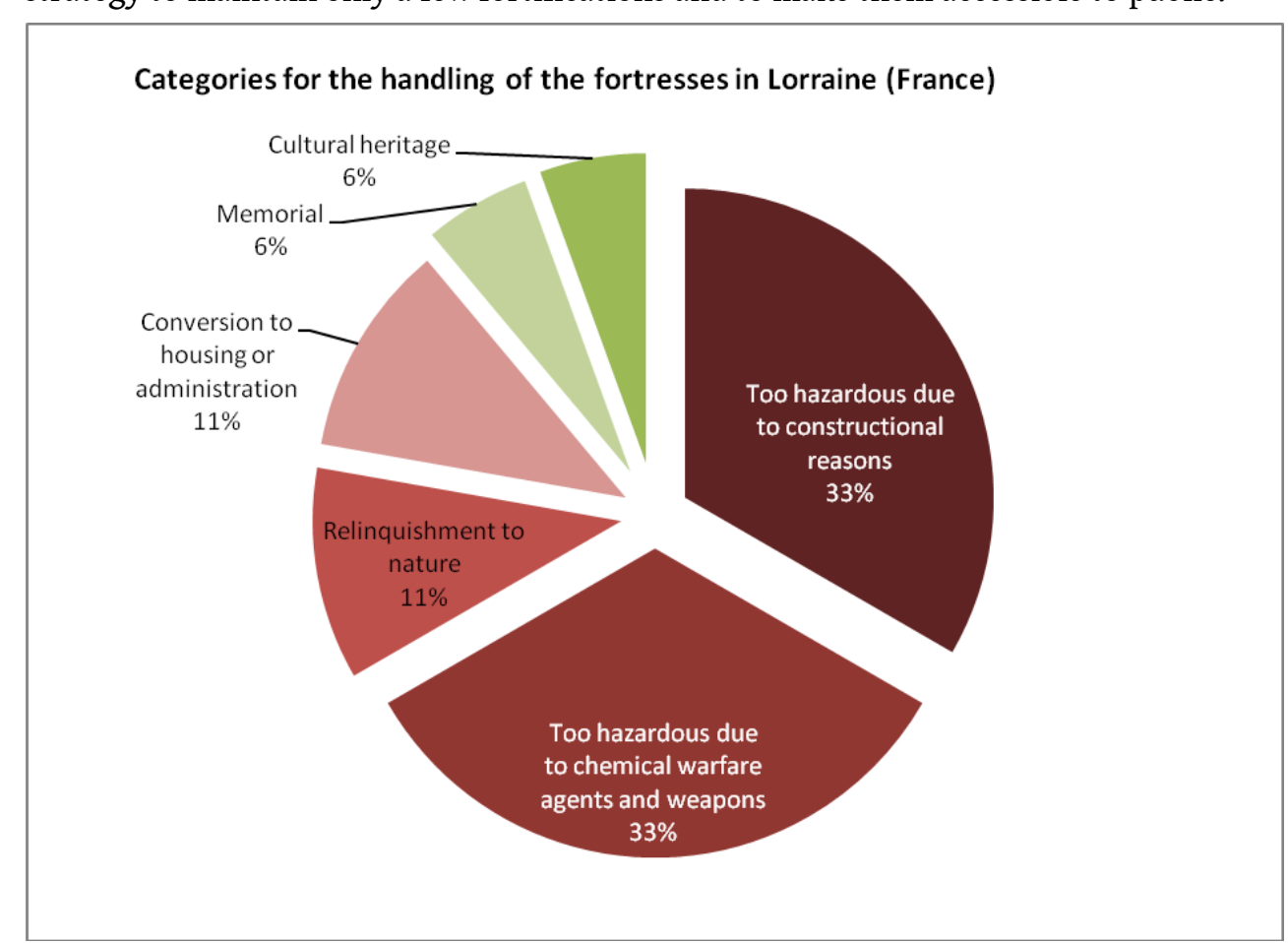

Figure 3 Categories for the handling of the fortresses in the French area ${ }^{3}$ 
For that purpose the institution for care and preservation of monuments in Lorraine has worked out the following categories ${ }^{4}$ (figure 3):

- For constructional reasons, one third of the fortification sites are considered to be too hazardous for maintenance.

- Another third is unsuitable for further utilization, because there is a risk emanating from still existing chemical warfare agents or weapons. This primarily applies to fortifications located in the combat zones of World War I.

- About $10 \%$ of the fortifications are relinquished to nature, because threatened species like bats for example have nested there.

- Further $10 \%$ are subject to conversion to living quarters or administration departments.

- In the end, only about $10 \%$ make up those fortifications that are or might be valorised and used as a memorial or cultural heritage. In this category, for Lorraine certain archetype sites have been chosen, which are to be preserved as outstanding examples of fortification architecture ${ }^{5}$.

17 In order to develop professionally, these sites valorised as memorials or cultural heritages are partly subsidised with tremendous financial means by the French government. This becomes especially clear using the example of the artillery structures Simserhof of the Maginot Line. In 2002, in order to turn the structures into a multimedia-based museum of world wars, already 5,2 million Euros have been invested for the first reconstruction phase. In succession, further annual low-scale investments have been made, lastly in 2010 with an amount of 500000 Euros for the installation of up-to-date video technology. Till 2012 the whole location is to evolve above- and underground into a fortification theme park by means of further investments.

Another large-scale project is the valorisation of the fortification sites on Mont St. Quentin near Metz. Mont St. Quentin with its four fortification sites (Fort Girardin, Fort Diou, Fort Saint-Quentin and Fort Plappeville submontane) poses an important local recreation area that overtops the town, offers great views and additionally comes up with a number of sights with edificial structures of fortifications. The city of Metz adjudicates upon the location as follows: "A location especially suited for promenading and exploring. A location with historical heritage and educational value" (Metz Métropole, 2010). Between 2005 and 2020 a total investment of 24 million Euros will secure the area, open it to public and valorise it for guests and tourists (Metz Métropole, 2010). 


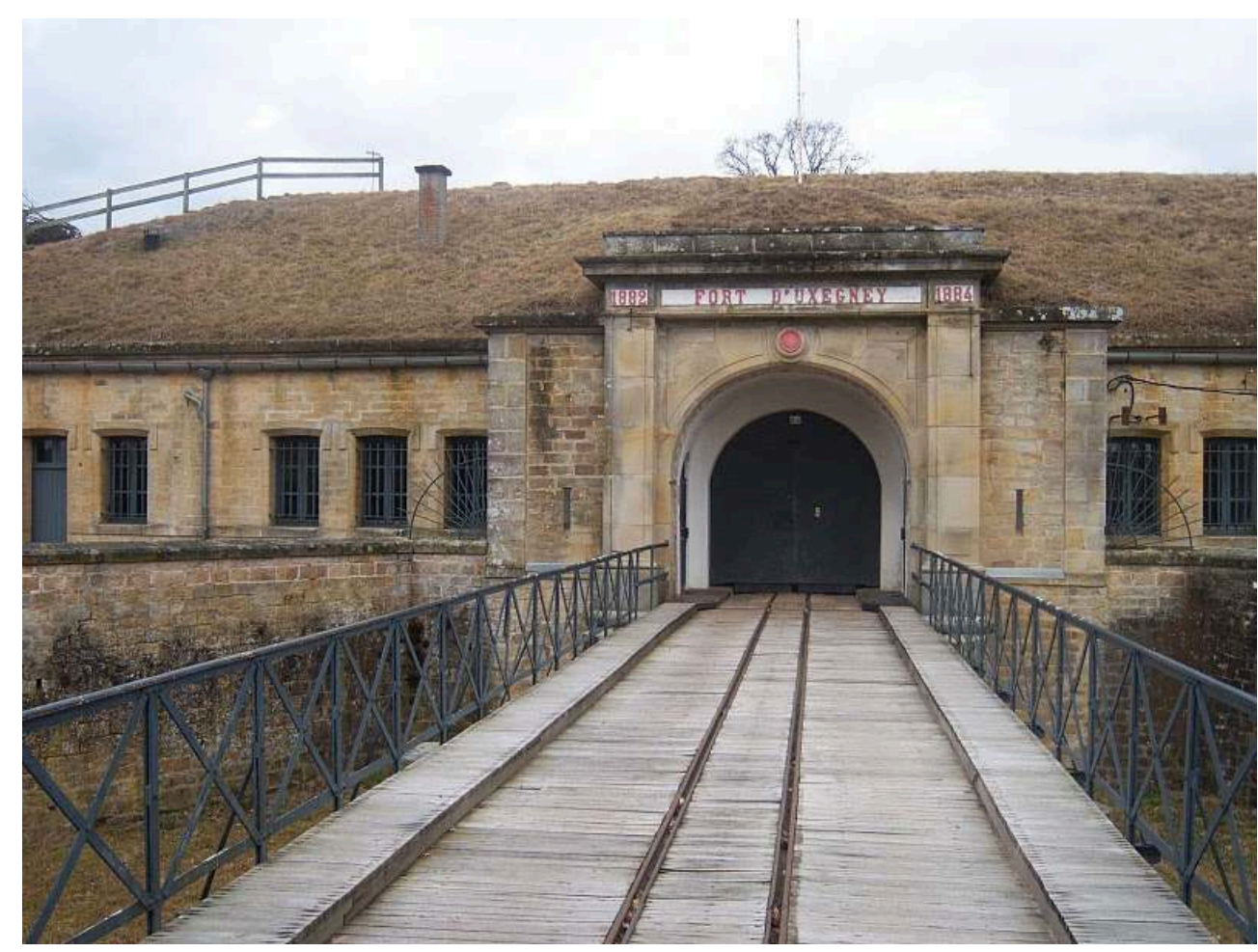

Figure 4 The Fort d'Uxegney near Epinal as an archetype site for the 19th century in Lorraine.

Beside these archetype sites there are a number of fortifications preserved by the work of non-profit associations, too. Due to their high dedication, fortifications are refurbished, preserved and even made accessible for visitors. Not least the fortifications are an integral part of tourism related marketing and are intensely merchandised with prospects and via the internet.

So in Lorraine there is a chance to preserve a broad spectrum of fortifications from all epochs. But since this part of the border region is overstrained with preserving all fortifications due to the multitude of objects, a sizable portion deteriorates. This eventually means the irretrievable loss of cultural heritage. However, Lorraine deals very self-consciously with the fortifications applying its pragmatic valorisation strategy by means of selected archetype sites and furthermore preferably places them under preservation order. The combination of professional valorisation by the government, offensive marketing by the tourism organisations and the non-profit work of small associations seems to be suitable to preserve a major number of fortifications originating in hundreds of years of territorial history for posterity. 


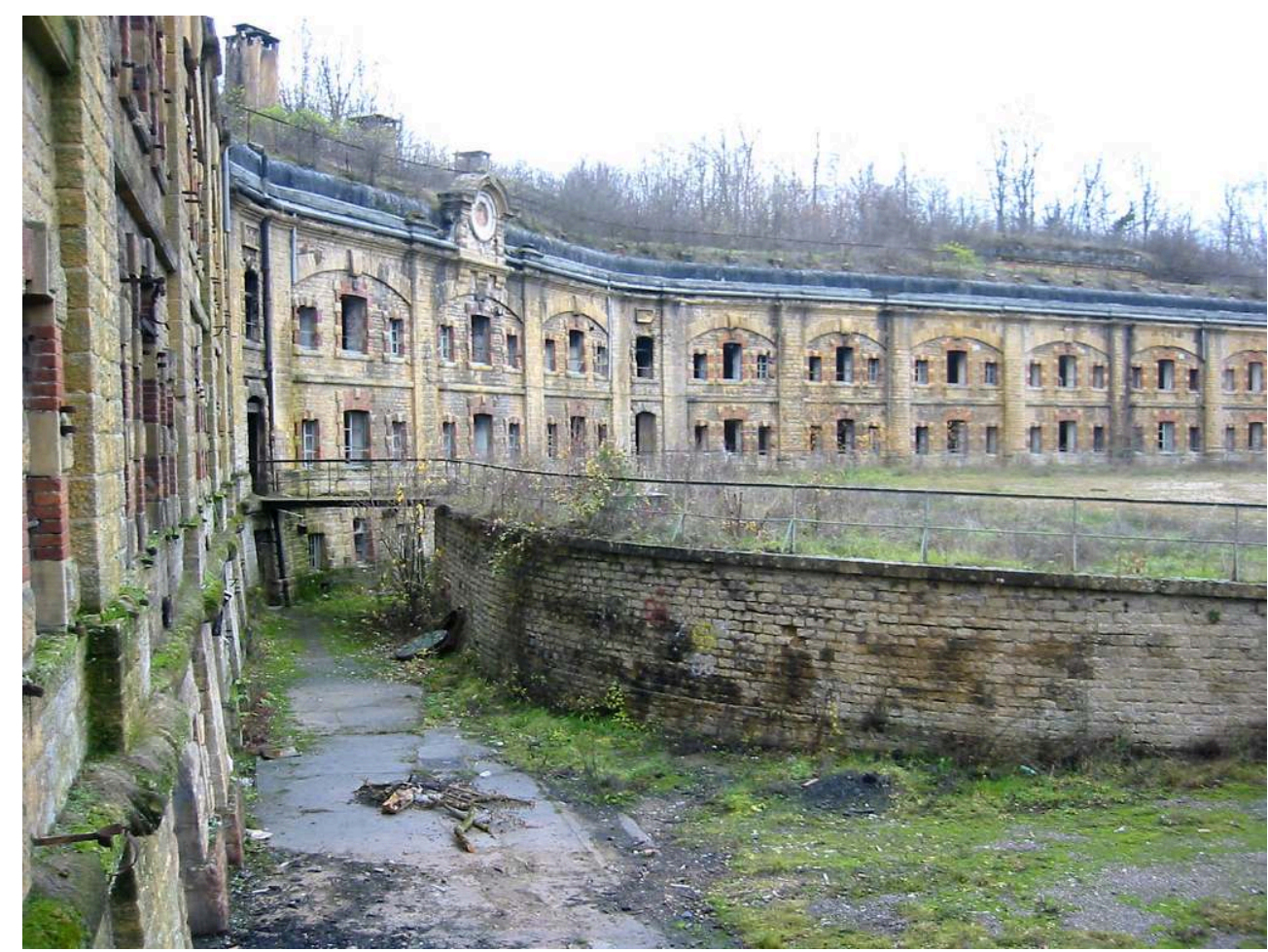

Figure 5 Central barracks of submontane Fort Plappeville at Mont St. Quentin.

\section{B - Luxembourg - a revived fortification under UNESCO protection}

21 In Luxembourg we face a completely different situation. Even though there is only one fortified place built during the time of modern fortification construction epochs, the fact that it has been called "Gibraltar of the North" indicates its significant military importance in history. The fortress Luxembourg can be considered a European collaborative work, because from the 16th century until the year 1867 in the role of the respective occupant the Spanish, Burgundians, Austrians, French and Prussians have contributed to its construction and enhancements. In 1994, the historic centre with its fortifications has been admitted to the World Cultural Heritage list, because of the important role Luxembourg played in the course of history, and due to the edificial heritage of fortifications, where the variant rulers became manifest in.

What makes the situation in Luxembourg so special is that the fortifications have been slighted for the very major part. In 1867, as a result of the agreement between emperor Napoleon III and Bismarck, the surface fortification sites have been eliminated and the demolition rubble has been used for backfilling the diggings. But then the utilisation of the fortification relics for tourism started very early, that is to say in 1933. In that year parts of the subterranean mine corridors and casemates were made accessible for guided tours.

In connection with the inclusion of the historic centre's fortification facilities in the World Heritage List, a renaissance of the fortification idea has occurred. This caused not only that the still existing fortification sites have been valorised, but also that some parts were even reconstructed. Luxembourg experienced high attentiveness as a result of these reconstruction measures initiated by Georges Calteux, director of the bureau for preservation of monuments in Luxembourg ${ }^{6}$. Beginning in 1997, one of the 
fortification fronts, the Pfaffenthal heights, has been completely reconstructed. These measures comprise the following main elements:

- the restoration of the Vauban towers,

- the reconstruction of bastions belonging to the forts of Niedergrünewald, Obergrünewald and Thüngen,

- the opening of a fortification museum in fort Thüngen and

- the establishment of the Vauban path as a loop road for tourists connecting all locations with a single trail.

24 A total of 34,6 million Euros has been provided by the government for the Vauban path and the fortification museum (Frenn vun der Festungsgeschicht Letzebuerg, 2010). So just like in Lorraine - the capital expenditure is very high, which probably arises from the significant importance of that fortress for Luxembourg as well as from the financial strength of the country.

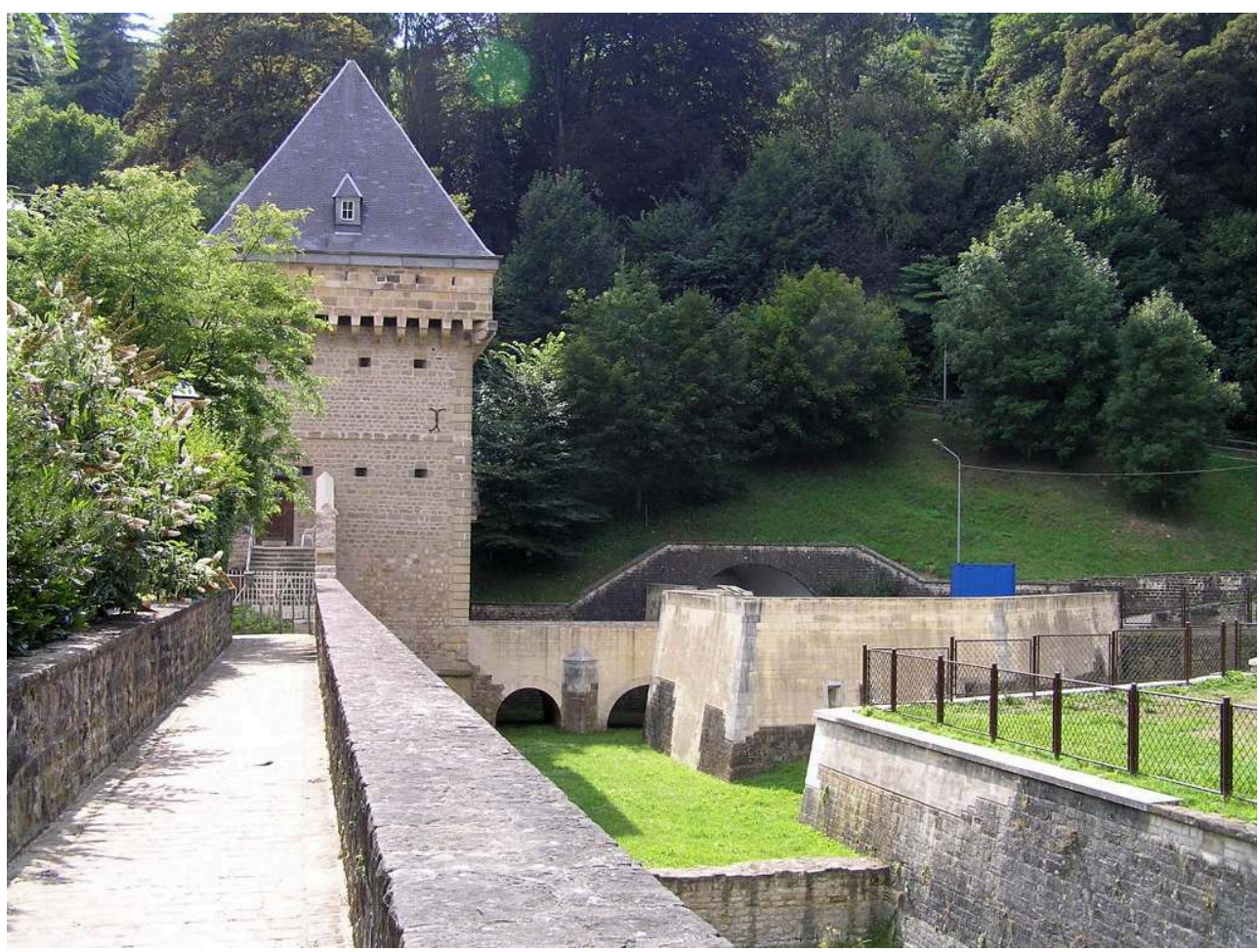

Figure 6 Vauban tower with reconstructed battlements (the brighter parts of the battlement in the right-hand half of the picture).

At the same time a dedicated fortification association, the "Friends of Fortification History Luxembourg", came into existence, which achieved unforeseen successes reflected by the considerable quantity of 600 members. The association offers guided tours through parts of the fortress that are usually not open to public. Among those are tours leading through the approximately 17 kilometres long mine corridors and casemate system. The "Friends of Fortification History Luxembourg" are an indispensible power for maintaining and valorising the fortification sites. Not least to their efforts the consciousness for the existence of these slighted but formerly important fortification sites have grown. From that time on this led to extensive measures for unearthing, safeguarding and reconstruction. Also in connection with nowadays measures in regard to urban development, the facilities existent in subsoil are dealt with in a gentle and preservation-oriented way. 
Since Luxembourg owns only one large fortification site, which is appreciated by the resident population, there is a chance to depict the evolution of fortification history since the middle ages within a minimum of space. The high commitment of single persons as well as the fortification association of Luxembourg makes this happen with a significant capital expenditure and in a professional manner which appealingly valorises the fortification relics. The fortifications are indeed not placed under national preservation order, but are listed in the UNESCO Convention on the Protection of the World Cultural and Natural Heritage. However, it is problematic that the measures and initiatives to preserve and to valorise the fortress are not standard practice, but mainly a result of two persons' dedication. Therefore, one cannot speak of a sustainable acting in Luxembourg. But due to the fortification association, having a large membership and having grown over the past 15 years, and due to the city's tourism organisation there is a solid base for advanced level fortification tourism worthy of serving as an ideal for other countries.

\section{C - Germany - absence of awareness and lack of appreciation}

Lastly we want to have a glance at Germany. Here the handling of edificial heritage of fortifications is rather perceived as a problem, which up to now for the most part prevented a successful and regarding tourism effective valorisation. As a result of recent German history there is a certain timidity to deal with fortifications unprejudiced and to stage them for visitors. Hence, the appreciation of the edificial heritage of fortifications as cultural assets is rather an exception than the rule. Even nowadays fortification relics are demolished or superstructed. After all in many places the influence fortification sites can have on visitor flows has not been realized, yet.

The demolition of fortification facilities continues even nowadays. As a general rule, the structures' disposal is reasoned (politically or edificially) using keywords like "obstructive", "unaffordable" or "unalluring". In the end, this argumentation is evidence of our society's disability "to integrate history into present dynamic and future strategy" (Eberle, 1995). This shall be briefly illustrated on the basis of the fortification town Saarlouis and the Siegfried Line as examples.

In Saarlouis, a fortification town of Louis XIV of France, a commercial premise close to the city centre has been abandoned. With ongoing demolition it became apparent, that important relics of the bastionary enclosure from the 17th century are located underground (Werres, 2008). Even though experts for fortifications pointed out the meaning of these fortification relics, the city of Saarlouis replanned land development in that area for high-quality residential buildings. Though there were numerous protests, the city's administration did not deviate from its construction project. Only a few of the well-preserved fortification relics were to be integrated into the new construction as decorative elements. But since it was difficult to find enough buyers for the owner-occupied flats, the land development plan has not been realized. Afterwards a rededication of that area was conducted, so after all the fortification relics now are preserved and integrated into the green space plan of the city park (Werres, 2010). This preservation of the heritage is not owed to the will of the city's administration but to the failure of the planned construction project. 


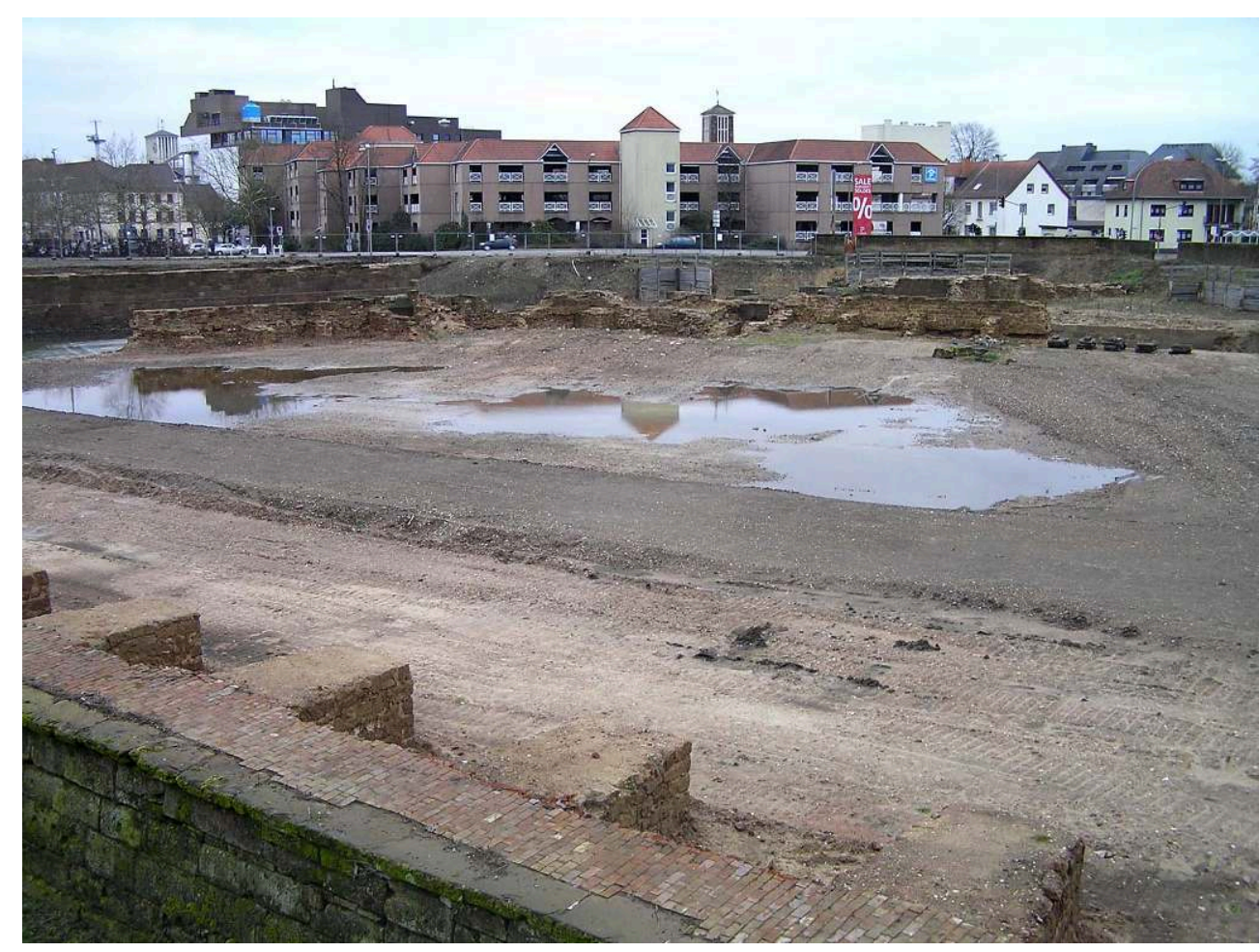

Figure 7 Abandoned commercial premise in Saarlouis with the relics of the bastionary enclosure.

Removals occur much more often in the range of the Siegfried Line. The reasons for this are manifold :

- Bunkers and tank traps are often built on farmland interfering with the agricultural use and therefore are removed.

- In addition, it is questioned that fortifications and defensive structures can be used in a different way than as historical monuments or memorials and even this seems not to be very attractive.

- Moreover, nationalistic activities of right-wing groups are feared.

- Finally, the state as owner of a large part of the Siegfried Line insists on the "Compliance with the obligation to safeguard traffic ${ }^{7 /}$ and has bunkers being removed, buried or safeguarded over a wide area.

31 Due to the massive construction, the deterioration wears on slowly and the expenses in the event of a demolition are too high, so many bunkers of the Siegfried Line still exist today. The expression "cadaver of past malpractice" or "monuments of a historic meander" make clear that "in the minds of the broad population they are rejected as dangerous and glorifying violence and are not associated with the positive connotated term "cultural assets" (Kierdorf and Hassler, 2000).

Actually, it seems that until now other countries value German fortifications higher than Germany itself. This is evidenced by the sell of tank barrier parts to a Texan in 2004. Now he exhibits the tank barrier in his private museum in Dallas. Scheid, the local authority concerned, appreciated the sale since it wanted to build a connecting path to make agricultural areas within the range of the tank barrier accessible (Heinen, 2004). This is the only sale of that kind so far. However, it reveals the low appreciation of the recent fortification epoch in Germany. 

Siegfried Line is avoided. Only a few structures have been made accessible. Among these are some small bunkers that single persons converted into private museums. The office for preservation of historical monuments in Saarland judges the latter as follows : „Precisely the presentation and museum-like usage of the facilities belonging to the Siegfried Line is often limited to the virtue of pure military history and fades out the context of their origination and utilisation"s. This kind of valorisations often concentrating on the authentic arrangement of weapons and facilities within the bunkers does not seem to be the right way to attract larger groups of people or laymen concerning fortifications.

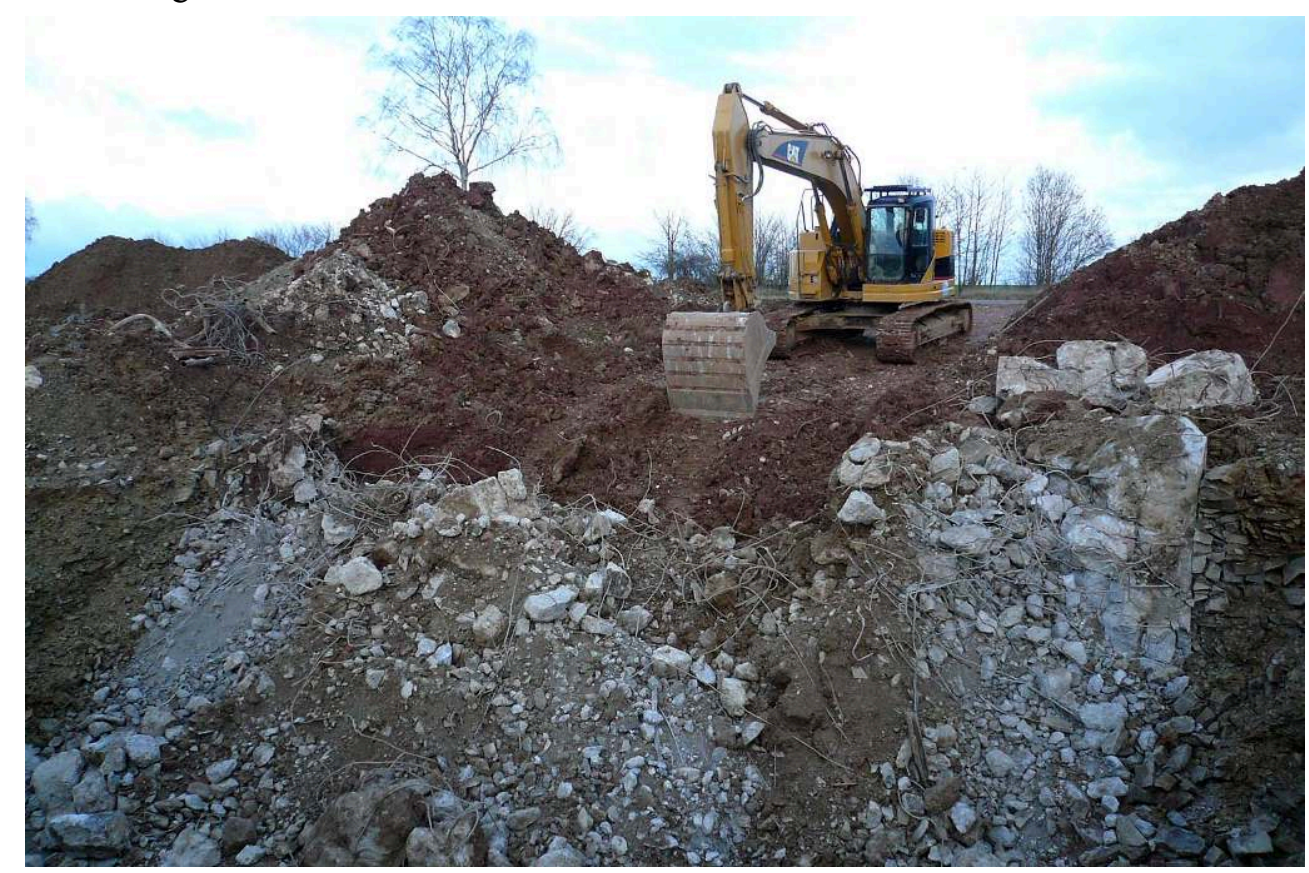

Figure 8 Removal of a Siegfried Line bunker close to Zweibrücken

Also Saarland's Tourist Board can not notice any great attractiveness concerning edificial heritage of fortification. Fortifications already made accessible for public are not seen as attractive in no way. "There is neither the endogenous potential and attractiveness of the sites available nor is there a deduced potential [for tourism]. There are no events [...], deficits in staging, lack of professional marketing and structural problems. This hinders any valorisation. There is no potential for tourism far and wide in the end, tourism concerning fortifications is no "topic lying on the surface" ${ }^{9}$ the more so as also existing sites are lacking a seasonable appeal to visitors. These statements reveal the lacking consciousness for touristic potentials of fortifications and the lack of appreciation of fortifications as a cultural heritage.

Thus, some problems in Germany are to be stated. The recent edificial heritage of fortifications is not appreciated and the awareness of the tourism potentials is missing. Until now fortifications and parts thereof are torn down and superstructed. Since German history constitutes an inhibiting factor for a more self-confident handling of the national socialist fortifications, there is the risk that the Siegfried line and therefore a whole fortification epoch will be repressed and concealed. But a positive aspect is that numerous fortifications already have been put under preservation order by the Society for Preservation of Historical Monuments. With the amendment to 
Saarland's Preservation of Historical Monuments Act it should be even possible to put the Siegfried Line as a whole under preservation order (Landesdenkmalamt des Saarlandes).

\section{D - Interim Conclusion}

In many respects the edificial heritage of fortifications constitutes a great challenge for the parts of the border region.

- The fortification structures were built as mere defensive structures making a conversion more difficult.

- Today, reflecting the unpleasant and not so nice aspects of history, they ask for an exceptionally sensitive handling.

- Even if there is a distinctive willingness - like in France and Luxembourg - to preserve and valorise fortifications, financial restriction will impede this enterprise.

For this reasons $83 \%$ of the 600 fortifications in the border region Germany-FranceLuxembourg lay waste and deteriorate bit by bit (Reichert 2005). For most of the structures are not used since their military decommissioning, the missing care causes massive damages to the basic structure and may lead to a structural collapse. Frost and root wedging as well as wilful destruction cause damage to the edificial structures and informal user leave their mark in form of graffiti, piles of rubbish and car wrecks.

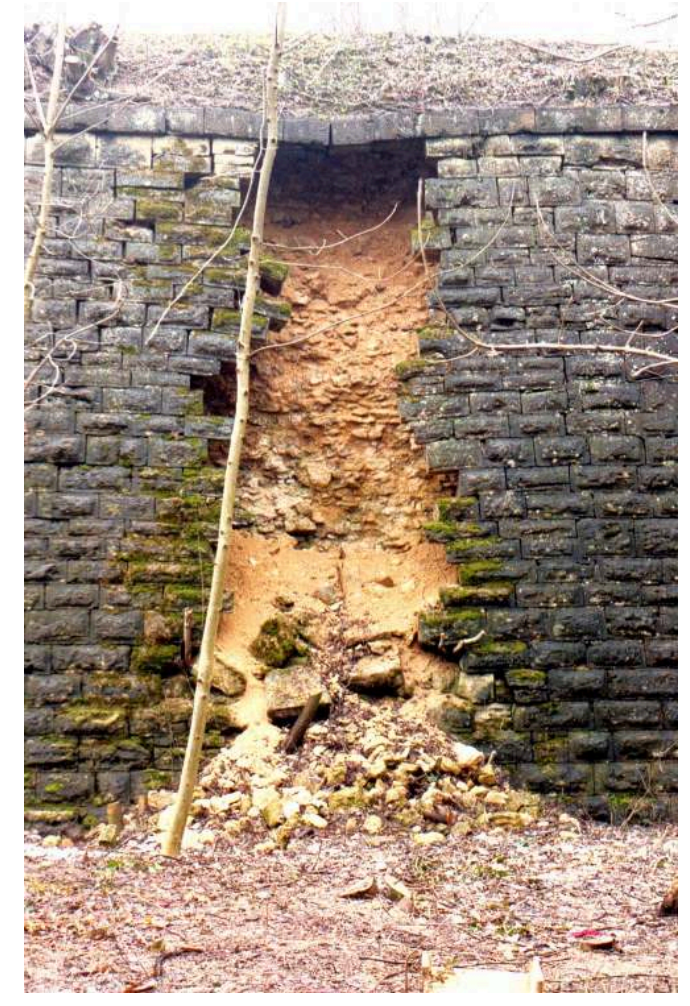




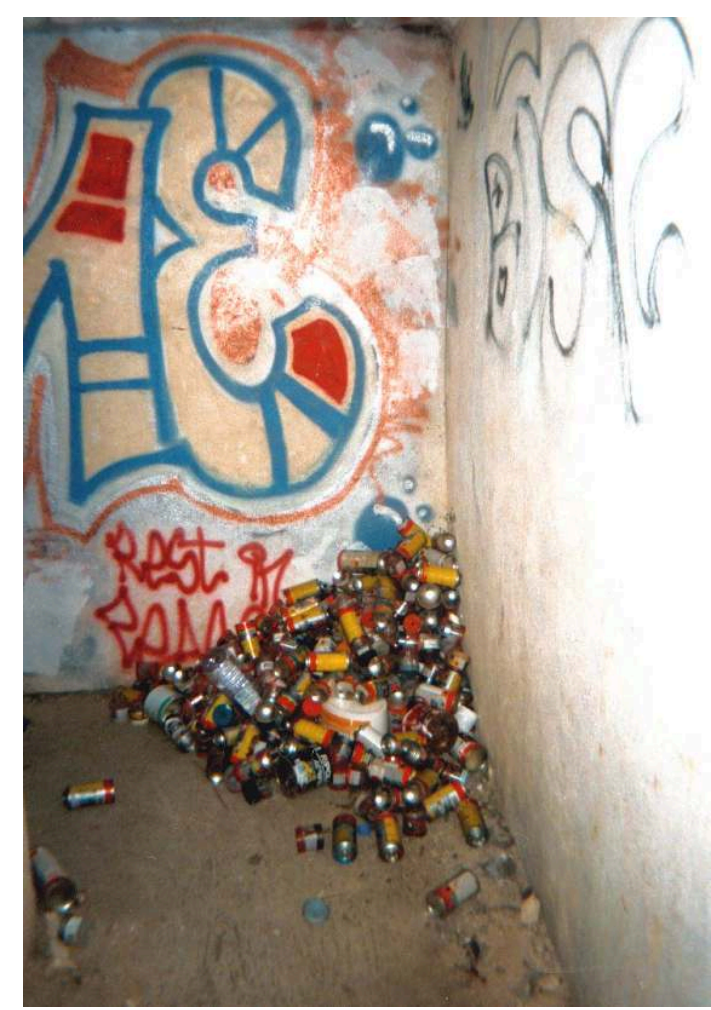

Figure 9/10 Root wedging at a bastion wall in Longwy (France) and wilful destruction by graffiti and piles of rubbish in Thionville (France)

In France and Luxembourg the remaining $17 \%$ of the structures are in general and concerning fortification tourism looked upon favourably and made accessible. This acceptance is reflected in a large attendance. Fortifications in Luxembourg attract about 100.000 visitors per year. The 35 sites that can be visited in Lorraine attract roundabout half a million tourists. In contrast the Siegfried line bunkers, opened to public in the German part of the border region, attracts just about 12.000 visitors (Reichert, 2005).

In Lorraine not less than approximately 25 associations dedicate themselves - mostly with great commitment - to the preservation and visitor-oriented utilization of fortresses. The association of fortifications based in Luxembourg impresses with its large membership. In Germany, however, neither a significant number of visitors is observed nor try dedicated associations to preserve them.

In the area of the preservation of historical monuments and the organisation of tourism, the differences do not seem to be so clear. While especially in Lorraine and the Saarland the preservation of historical monuments emphasizes that fortifications are worthy to be preserved by putting them under preservation order, it seems to be irrelevant in Luxembourg, but is outweighed by the supranational status as world cultural heritage. Concerning the appreciation by persons responsible for tourism, it is to be observed that in France and Luxembourg fortifications are an inherent part of the cultural attractions for tourists, while in Germany their endogenous potential for measures making them accessible for tourists are slowly realised. 
Table 1 Results of the comparison

\begin{tabular}{|c|l|l|l|}
\hline & France area & Luxembourgian area & German area \\
\hline $\begin{array}{l}\text { Fortifications accessible to visitors } \\
\text { (with entrance fee) }\end{array}$ & $17,6 \%$ & $\begin{array}{l}100,0 \% \\
\text { (but only one fortified } \\
\text { complex) }\end{array}$ & $2,5 \%$ \\
\hline Amount of tourists per year & 500.000 & 100.000 & 12.000 \\
\hline Number of associations & 25 & 1 & 2 \\
\hline Associations: number of members & $\sim 1.500$ & $\sim 600$ & $\sim 250$ \\
\hline $\begin{array}{l}\text { Support the tourism } \\
\text { organisations }\end{array}$ & & & \\
\hline $\begin{array}{l}\text { Promotion by the Preservation of } \\
\text { historical monuments }\end{array}$ & & & \\
\hline
\end{tabular}

\section{E - Excursus: Status quo of the cross-border co-operation}

41 At the moment, in the region SaarLorLux there are only scattered cross-border cooperation amongst the agencies responsible for the sites developed for fortification tourism. For instance, for the organization of group travels in the border region there exists a collaboration of both the bureaus of tourism in Saarland and those in the Département Moselle in Lorraine. Among these one can also find offers in conjunction with the heritage of fortification (Zukunft SaarMoselle Avenir / Tourismusbüros von SaarMoselle, 2009). But the most protagonists do not expect a significant gain from collaboration. In addition, in particular the associations working pro bono are focused so much on their own activities that up to now co-operations could come into being only in exceptional cases.

There is also the fact that protagonists from all parts of the border region consistently state, that cross-border cooperation proves to be complicated and circuitous. The differences in administration and mentality are reported to be tremendous. Problems already arise from the fact, that there is no direct counterpart in the respective neighbouring country due to different ways administration is organized. Responsibilities centrally bundled at one department in one country are scattered across various departments in the neighbouring country. In addition, there are diverse interests and objectives which hamper a joint stringent strife for a common goal. These different interests manifest in restoration ethics for instance. Whilst in Luxemburough and Germany mainly reconstructions are accomplished, these are completely refused in 
France and carried out only in exceptional cases. Amongst others, problems can be traced back to the form of government. Whereas Germany is federally organized and the lower level of townships actually holds authorities to decide, France is organized in a centralized way and important decisions are only to be made in the capital of Paris. In addition, there are differing township extents. The fortification sites in Lorraine mostly are situated in small townships that are financially very weak. The townships in Saarland are very widespread instead. Furthermore, in regard to culture there is no real will for harmonization. One protagonist resumed: „Cross border collaboration is good for political soap-box oratories, but hard to achieve in reality." ${ }^{10}$ Another actor constituted: „The challenges of cross-border co-operations are that huge, that the desire for joint projects needs to be tremendous ${ }^{{ }^{11}}$ to succeed in overcoming all obstacles dedicatedly and determinedly.

Nevertheless, there is an approach for cross-border co-operation existing, which could in future develope favorably and therefore is to be introduced briefly. In 2007 the "Network of Fortified Towns" came into being (Werres, 2007). This is a union of fortified towns in the German-French-Luxembourgish border area. The towns Bitche, Longwy, Luxembourg, Marsal, Montmédy, Rodemack, Saarlouis, Sierck-les-Bains, Toul as well as the municipalities associations of Bitche and Cattenom belong to this network. The aim is to valorize, revive, network and to exploit the fortification heritage jointly, thus generating awareness of it among the population. The network wants to open the fortifications to the broad public and it wants them to be re-experienced including the cross border perspective offering tourist attractions as well as cultural, artistic and scientific projects. In 2007, the network had organized an event that attracted a great deal of attention, namely Citadelles de feu. During this event the fortifications have been staged very impressively using a light and fire show. Taking the cross-border idea into account the event took place in six different fortification towns within the border area. In 2010, the fortification town of Saarlouis repeated the event and attracted on a single evening 12.000 visitors into the fortress. In 2009, the Network has been awarded the „Kleiner Kulturadler" („The Small Eagle of Culture“) (O.A., 2009). Nonetheless, it has to be stated that this union is predominantly politically motivated up to now. Furthermore, with only nine fortification towns belonging to this umbrella organization, only a fractional amount of fortresses within the border area is integrated. However, this initiative offers potential links for a more intense and sustainable cross-border co-operation in order to preserve and valorize the edificial heritage of fortifications.

\section{III - Recommended Procedure}

In the following, some recommendations for next steps will be derived.

In order to keep the high level of design and valorisation measures in Luxembourg, a master plan for preservation and utilization of all fortification parts including a longlasting financial hedging should be developed. In that context a stronger complexion of the fortification topic as an essential element of cultural tourism in Luxembourg is to be strived for.

In Lorraine a strategy for preserving a larger number of fortifications should be developed. In addition the keen dedication of the persons responsible for tourism should be kept up and the voluntary commitment of non-profit associations should be 
encouraged. In that area exemplary achievements have already been made. The associations form a substantial backbone for the preservation of the edificial heritage of fortifications.

In Germany more effort is needed in order to strengthen the awareness of the historic importance of fortification sites and their preservation worthiness. The visitororiented valorisation of fortification sites is to be encouraged and integrated into the structure of attractions for tourists.

Not least the vision of a cross-border cooperation, which all region parts can benefit from, is to be developed and realized. By means of a collaborative approach, sustainable effects could be achieved and the tourism concerning fortification in the region SaarLor-Lux could be implemented.

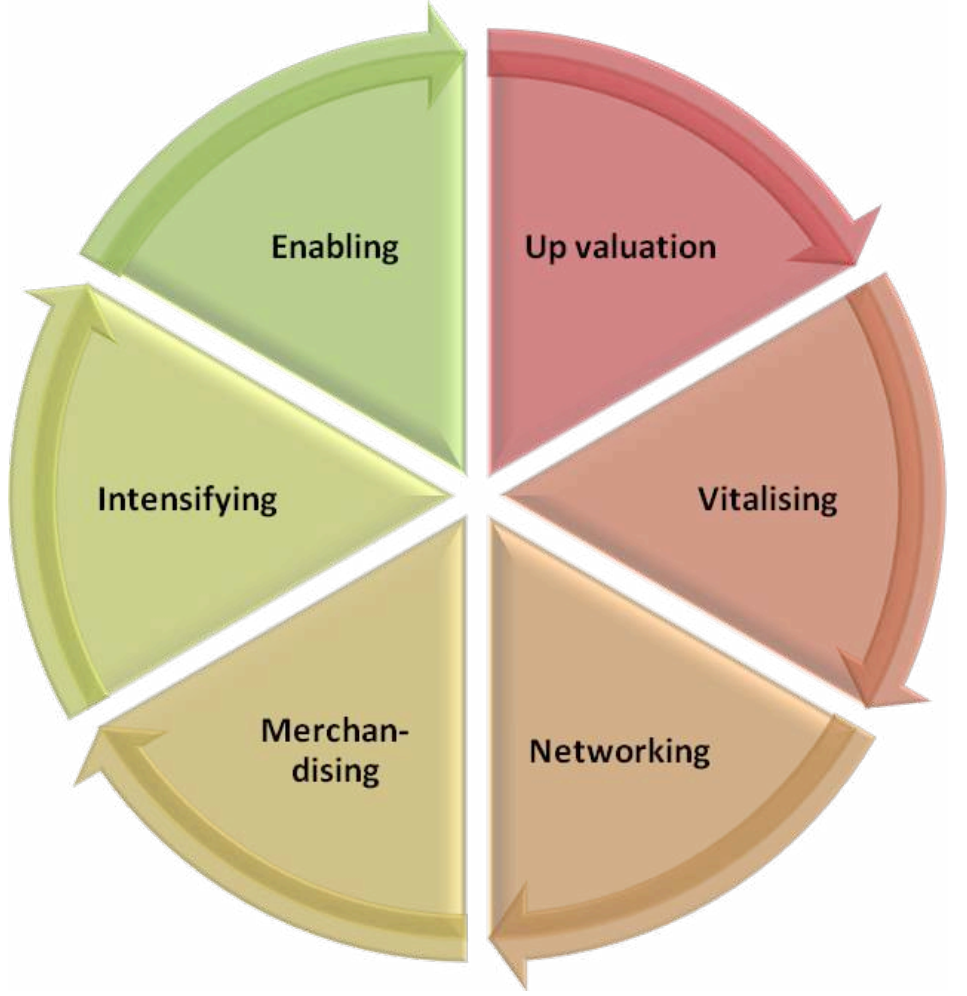

Figure 11 Cooperation objectives

The cooperation could aim for the following objectives:

- Up valuation of the fortifications by means of appealing visitor-oriented attractions and guided tours, which address a diversified public. In that aspect a joint apprenticeship and training of tour guides could take place.

- Vitalising the fortifications by transnationally arranging and conducting events in the fields of music, theatre, art, science or tradition. In that segment occasions such as the centenary of World War I in 2014-2018 can inspire various activities dealing with warfare and peace.

- Networking the fortifications. On the one hand by establishing admission alliances, on the other hand by means of a cross-border route for fortification tourism that could make use of the endogenous potential of the border region and stimulate awareness for the fortifications.

- Merchandising the fortifications by producing shared promotion material (posters, films or merchandising products), by establishing a collective internet presence and by issuing a transnational guidebook for fortification tourism. 
- Intensifying the existing approaches. Primarily this includes the „network of fortification towns", the union of nine fortification towns mentioned above. This initiative offers potential links for a more intense and sustainable cross-border cooperation.

- Enabling: In order to achieve these goals, it is eventually necessary to eliminate administrative and structural obstacles that prevent transnational cooperation.

\section{Conclusion}

50 beyond compare throughout the world. Their preservation and opening up for civil use may contribute to preserve a piece of European history and to create starting points for economic and local development. The mantles of past fortifications from 500 years of territorial history, which seemingly turned useless, also have to be preserved as witnesses of epochs characterized by wars, but altogether the facilities are convincing by architecture and diversity with regard to possibilities for subsequent use, which also accommodates an economic future.

51

France, Germany and Luxembourg as community of heirs should feel obliged to preserve and to further develop the shared heritage. For this cultural heritage constitutes a resource to promote cross-cultural dialogues and the potential for sustainable development regarding tourism. Making full use of the heritage is an essential factor in establishing the appeal of the border region. The preservation and maintenance of the fortresses is important, because they manifest human history with their positive and less positive aspects. To preserve them in all their diversity, is to show respect for the history and evidences a desire to build a better future while acknowledging the past. Fortification heritage should be managed in a sustainable way, recognising that it is an irreplaceable resource.

\section{NOTES}

1. With fortifications are meant modern history defence structures, built between the 16th and 20th century. In the following, the term fortification is always used in that regard.

2. The descriptions and comments are based on an interview conducted at the "Direction régionale des affaires culturelles de Lorraine" at Nancy with Mireille-Benedicte Bouvet, monument conservator and responsible for inventory, and Michel Prestreau, monument conservator. The personal communication took place on 23.03.2010.

3. Ibid.

4. Ibid.

5. These sites include the Citadelle Montmédy as representative of the bastionary Epoche of fortifications, the Ensemble of the Fort Uxegney, Bois l'Abbé and Sanchey near Epinal representing the 19th Century, the Fortresses Guentrange and Mont St. Quentin as representatives of the German fortification contruction in Lorraine, as well as the Maginot structures Fermont and Simerhof. 
6. The descriptions and comments are based on an interview conducted with Robert Wagner, president of the association "friends of fortification history Luxembourg". The personal communication took place on 16.03.2010 in Rippig.

7. The German term is "Verkehrssicherungspflicht"

8. The descriptions and comments are based on a statement in writing from Dr. Reinhard Schneider, Saarland state office for protection of historical monuments, based on a standardised questionnaire, Saarbrücken, 22.03.2010.

9. The descriptions and comments are based on an interview conducted with Birgit Grauvogel (Management Board) and Florian Kulik (Head of department city and cultural breaks) of the Saarland Tourism Board. The personal communication took place on 23.03.2010 in Saarbrücken.

10. The descriptions and comments are based on an interview conducted with Roland Pinnel, director of the Luxembourg City Tourist Office. The personal communication took place on 16.03.2010 in Luxembourg City.

11. The descriptions and comments are based on an interview conducted at the "Direction régionale des affaires culturelles de Lorraine" at Nancy with Mireille-Benedicte Bouvet, monument conservator and responsible for inventory, and Michel Prestreau, monument conservator. The personal communication took place on 23.03.2010

\section{RÉSUMÉS}

Avec plus de 600 ouvrages fortifiés, la région transfrontalière Saar-Lor-Lux présente une grande variété d'exemples d'architecture militaire. Il n'y a guère d'autre région qui puisse illustrer l'évolution de l'architecture militaire de façon aussi impressionnante. Cependant, le traitement réservé à ces fortifications varie beaucoup. En France et au Luxembourg, ils sont considérés comme un patrimoine de grande valeur. Une douzaine d'ouvrages fortifiés en France, ainsi que la citadelle de Luxembourg sont classés au patrimoine mondial de l'UNESCO. Leur statut de bien culturel n'est pas remis en question et l'on a beaucoup investi pour exploiter ce patrimoine. En Allemagne, la situation semble être à l'opposé. Les ouvrages fortifiés ne sont qu'exceptionnellement considérés de manière positive et reconnus comme des biens culturels. À partir de cet état des lieux, cet article a pour objectif d'étudier le traitement des ouvrages fortifiés dans les différents espaces de la région transfrontalière germano-francoluxembourgeoise. L'article présente également les mesures qui pourraient améliorer la reconnaissance des ouvrages fortifiés comme patrimoine culturel et générer des opportunités pour le développement d'un usage touristique transfrontalier.

With more than 600 fortifications, the border region Saar-Lor-Lux offers a wide variety of important examples of fortification architecture. Hardly another region is able to evidence the evolution of fortification architecture in such an impressive way. However, today's handling of fortifications varies a lot. In France and Luxembourg they are appreciated as heritage of high value. Twelve of France's fortifications and the fortifications in Luxembourg are on the UNESCO World Heritage List. Their acceptance as cultural property is not questioned and a lot is invested to utilize this heritage. In Germany, the situation seems to be the opposite way round. The positive reception of fortifications as cultural property is rather an exception. Based on these circumstances, this article has the aim to analyse the handling of fortifications in the different areas of the border region Germany-France-Luxembourg. Furthermore, the contribution explains 
measures, which could improve the acceptance of fortifications as a cultural heritage and presents opportunities which allow sustainable and cross-border touristic use.

Die Grenzregion SaarLorLux besitzt mit mehr als 600 Festungen eine Fülle an fortifikatorisch bedeutsamen Bauwerken. Kaum eine andere Region weltweit kann auf ähnlich eindrucksvolle Weise räumlich konzentriert die neuzeitliche Evolution des Festungswesens aus fünf Jahrhunderten dokumentieren. Der heutige Umgang mit den Festungen ist jedoch sehr unterschiedlich. In Frankreich und Luxemburg werden sie als bedeutsames kulturelles Erbe wertgeschätzt. Zwölf Festungen in Frankreich stehen seit 2008 auf der UNESCO-Welterbeliste, die Festungsanlagen von Luxemburg bereits seit 1994. Ihre Anerkennung als Kulturgut steht außer Zweifel und es wird viel in die Inwertsetzung dieses Erbes investiert. In Deutschland stellt sich die Situation umgekehrt dar. Die Wertschätzung des festungsbaulichen Erbes als Kulturgut bildet eher die Ausnahme als die Regel. Ausgehend von diesen unterschiedlichen Situationen, hat der Beitrag das Ziel, die Strategien des Umgangs mit dem festungsbaulichen Erbe in der Grenzregion $\mathrm{zu}$ analysieren und Maßnahmen zur Verbesserung der gesellschaftlichen Akzeptanz der Festungen $\mathrm{zu}$ erläutern. Schließlich sollen Möglichkeiten $\mathrm{zu}$ ihrer nachhaltigen und grenzüberschreitenden besucherorientierten Nutzung aufgezeigt werden.

\section{INDEX}

Mots-clés : fortifications, héritage culturel, mise en valeur touristique, pays frontalier, SarreLor-Lux

Schlüsselwörter : Festungen, Kulturerbe, touristische Inwertsetzung, Grenzregion, Saar-Lor-Lux Keywords : fortifications, cultural heritage, touristic valorization, border region, Saar-Lor-Lux 